Quality of table eggs on the Croatian market

Kvaliteta konzumnih jaja na hrvatskome tržištu

Kralik, Z., Grčević, M., Kralik, G., Hanžek, D., Zelić, A.

Poljoprivreda/Agriculture

ISSN: 1848-8080 (Online)

ISSN: 1330-7142 (Print)

http://dx.doi.org/10.18047/poljo.23.1.10

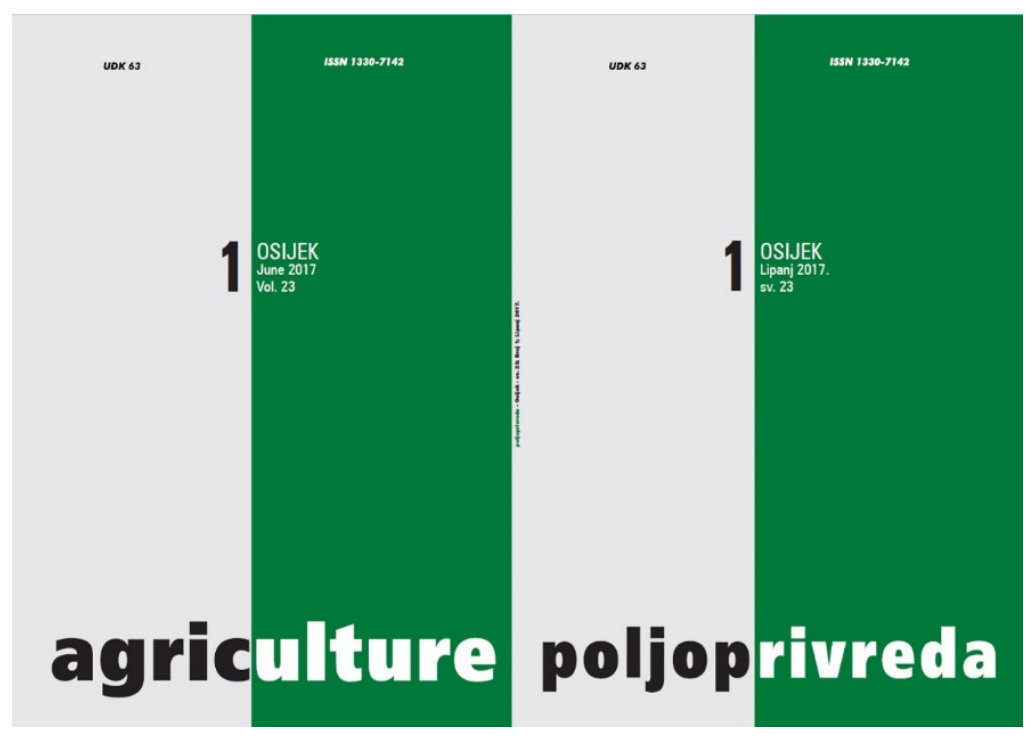

Poljoprivredni fakultet u Osijeku, Poljoprivredni institut Osijek Faculty of Agriculture in Osijek, Agricultural Institute Osijek 


\title{
QUALITY OF TABLE EGGS ON THE CROATIAN MARKET
}

Kralik, Z., Grčević, M., Kralik, G., Hanžek, D., Zelić, A.

Original scientific paper

Izvorni znanstveni članak

\begin{abstract}
SUMMARY
This paper investigates the physical and chemical quality indicators of table eggs available on the Croatian market. The research was carried out on eggs produced by two manufacturers, marked as $A$ and $B$, on the $7^{\text {th }}$ and $28^{\text {th }}$ day of egg storing. According to the Regulations on egg quality (0J 115/06, Art. 9), eggs are classified as class $A$ or fresh eggs and class $B$ or eggs for industrial processing. Referring to the weight of the eggs, the eggs of class $A$ are divided into four grades: $X L, L$, $M$ and $S$. Our research focused on the $M$ weight grade eggs, because they are the most represented ones in our conditions. The following external indicators of egg quality were analyzed: shape index (\%), egg weight (g), shell weight (g), shell strength $\left(\mathrm{kg} / \mathrm{cm}^{2}\right)$ and thickness $(\mathrm{mm})$. Furthermore, the following indicators of inner egg quality were tested: weight of albumen and yolk (g), yolk colour, Haugh units (HU), albumen height (mm), $\mathrm{pH}$ of albumen and $\mathrm{pH}$ of yolk. Results of our research provided the following conclusions: based on evaluation of energy and protein value, eggs of the manufacturer $B$ had better nutritive value than eggs of the manufacturer $A$. The results of research into quality of eggs on the $7^{\text {th }}$ day of storage proved that there was statistically significant difference $(P<0.001)$ between the $A$ and $B$ egg manufacturer if referring to the egg weight, shape index, shell thickness, shell weight and strength, as well as albumen weight. After the $28^{\text {th }}$ day of egg storage, there was statistically significant difference $(P<0.001)$ determined for albumen height, $\mathrm{HU}, \mathrm{pH}$ values of albumen and yolk, and yolk colour $(P=0.003)$. Based on the analysis of nutritive values and physical and chemical properties of eggs during storage, it was confirmed that eggs produced by the manufacturer $B$ were of better quality than eggs of the manufacturer A. Eggs of both manufacturers met the requirements defined by the Croatian Regulations on egg quality.
\end{abstract}

Key-words: table egg, quality, storing, the $M$ egg weight grade

\section{INTRODUCTION}

Eggs are an animal product consumed quite often because of their high nutritive value, easy preparation and diverse purposes. According to the Regulations on Egg Quality (OJ 115/06, Art. 9), chicken eggs are classified as class $A$ or fresh eggs, and class $B$ or eggs for industrial processing. Referring to the weight of eggs, eggs of class $A$ are divided into four grades: XL-very large eggs weighing from $73 \mathrm{~g}$ and more, L-large eggs weighing from 63 to $73 \mathrm{~g}$, M-middle-sized eggs weighing from 53 to $63 \mathrm{~g}$, and S-small eggs weighing less than $53 \mathrm{~g}$.

In Croatian conditions, consumers usually purchase eggs of the $M$ grade. Minimum shelf life must be indicated on the packaging of eggs, which is in accordance with the regulation provisions. The expiry date for eggs of class $A$ indicates the date until which eggs, if properly stored, retain their properties, as in the Article 10 of the aforementioned regulations. The minimum shelf life cannot be longer than 28 days after laying until being sold to the end consumer. The laying date shall be visible on all eggs in a package. This research focused on determining the changes that occur in egg yolk and albumen by the $28^{\text {th }}$ day of storage in a refrigerator at $+4^{\circ} \mathrm{C}$. The examined eggs were purchased within the recommended

Assoc. Prof. Zlata Kralik (zlata.kralik@pfos.hr), Manuela Grčević, PhD, Prof. Emer. Dr. Dr. h. c. Gordana Kralik, Danica Hanžek, M. Eng. Agr., Ana Zelić, PhD student - Josip Juraj Strossmayer University of Osijek, Faculty of Agriculture in Osijek, Department of Zootechnique, Chair of General and Special Zootechnique, V. Preloga 1, 31000 Osijek 
shelf life. The most significant changes in the quality of eggs can be assessed by qualitative indicators, such as: Haugh units, weight of albumen, egg yolk and shell, albumen height and $\mathrm{pH}$ of yolk and of albumen, as well as moisture loss through shell pores (Jin et al., 2011). Egg weight is an important property that affects the quality and class (Farooq et al., 2001; Sekeroglu and Altuntas, 2009). According to Burley and Vadehra (1989), albumen consists of an outer layer (23.3\%), inner layer (16.8\%), and middle, dense layer $(57.3 \%)$ and chalazae $(2.7 \%)$. The shell protects the content from microorganisms and small predators (Hincke et al., 2012). During storage of eggs, chemical processes occur in albumen and yolk. One part of water evaporates from albumen, and one part enters the yolk, thus increasing its volume and weight (Scott and Silversides, 2000). The aim of this research was to assess the quality of eggs of the $M$ grade (53-63 g) produced by two different manufacturers, referred to as manufacturer $A$ and manufacturer $B$. Eggs were purchased in a supermarket, on the $7^{\text {th }}$ and $28^{\text {th }}$ day of storage. The intention was to determine whether there are differences in the quality of eggs of two different manufacturers, as well as in the physical and chemical properties that occur in eggs during storage period.

\section{MATERIAL AND METHODS}

The research was carried out on a total of 120 eggs produced by manufacturer $A$ and manufacturer $B$. After the $7^{\text {th }}$ day of storage, 30 eggs of each manufacturer were analysed for their external and internal indicators of egg quality. The same analysis was performed after the $28^{\text {th }}$ day of storage, also on 30 eggs of each manufacturer, with the aim to determine physical and chemical changes that occurred during storage period in the yolk and albumen.

The following indicators of external egg quality were analysed: length and width of eggs $(\mathrm{mm})$, shape index $(\%)$, egg weight $(\mathrm{g})$, shell weight $(\mathrm{g})$, strength $\left(\mathrm{kg} / \mathrm{cm}^{2}\right)$ and thickness $(\mathrm{mm})$ of shell. The following internal indicators of egg quality were analyzed: weight of albumen and of yolk $(\mathrm{g})$, yolk color, Haugh units (HU), albumen height $(\mathrm{mm}), \mathrm{pH}$ of albumen and $\mathrm{pH}$ of yolk. Shape index was calculated from the measures of length and width of eggs according to the pattern: index of shape $(\%)=$ width of eggs/length of eggs*100 (Panda, 1996). The weight of the eggs and main parts (albumen, yolk and shell) was measured by the PB 1502-S scales. An automatic device Eggshell Force Gauge Model-II was used to measure the egg shell strength. Shell thickness was measured in the middle of the shell by an electronic micrometre with precision of $0.001 \mathrm{~mm}$. The measurement was performed three times to calculate the average. Values of $\mathrm{pH}$ of albumen and yolk were measured by the pH meter MP 120 . Yolk color, Haugh units (HU) and height of albumen were measured by the Egg Multi-Tester EMT-5200.

Research results were processed by Statistica v.13.2. (Dell Inc., 2016.). The significance of differences testing between and within the groups was performed by applying the GLM procedure of the variance analysis (ANOVA). The following statistical plan was applied: $2 \times 2$ treatments; treatments: manufacturer $A$ and $B$, storage 7 and 28 days. The calculated $F$ value was compared with critical theoretic $\mathrm{F}$ value at the significance level $(P<0.05, P<0.01$ and $P<0.001)$. Significance of differences between mean values was determined by the Fisher's LSD test.

\section{RESULTS AND DISCUSSION}

The Table 1 presents indicators of table egg quality referring to the weight of whole eggs, shape index, the weight of albumen and of yolk, as well as weight, thickness and strength of the shell. Although both groups of eggs were of the $M$ grade (53-63 g), it was determined that eggs of the manufacturer $A$ weighed less on the $7^{\text {th }}$ storage day than eggs of the manufacturer $B(55.75$ $\mathrm{g}: 57.89 \mathrm{~g}$ ) and that they also had lower shape index (76.67\% : 79.04\%; $P<0.01)$. Eggs of the manufacturer $B$ had stronger shell $\left(3.52 \mathrm{~kg} / \mathrm{m}^{2}: 2.51 \mathrm{~kg} / \mathrm{m}^{2}\right)$, and this property is related to thickness and strength of shell $(\mathrm{P}<0.001)$. Our research confirmed that eggs of both manufacturers had thicker egg shell than it was reported by Suksombat et al. (2006) and Hanusova et al. (2015). The albumen weight $(\mathrm{g})$ analysis indicated statistically significant influence of the manufacturer $(\mathrm{P}<0.001)$.

Eggs of the manufacturer $B$ had better results for the stated indicators. Interaction of the influence of egg manufacturers and the storage period was not statistically significant $(P>0.05)$. Egg weight is an important indicator that affects quality and classification of eggs (Farooq et al., 2001). It is in direct proportion to weights of albumen, yolk and shell. Portion of albumen (\%) was lower in lighter eggs, and that of yolk was greater in heavier eggs (Kaminska and Skraba, 1991), which was also confirmed in our research.

Table 1. Indicators of table eggs quality

Tablica 1. Pokazatelji kvalitete konzumnih jaja

\begin{tabular}{|c|c|c|c|c|c|c|c|c|}
\hline \multicolumn{2}{|c|}{ Treatments - Tretmani } & \multirow[b]{2}{*}{$\begin{array}{c}\text { Egg weight, } \\
\text { Masa jaja } \\
\text { (g) }\end{array}$} & \multirow{2}{*}{$\begin{array}{l}\text { Shape index } \\
\text { Indeks } \\
\text { oblika } \\
(\%)\end{array}$} & \multirow{2}{*}{$\begin{array}{c}\text { Shell } \\
\text { thickness } \\
\text { Debljina ljuske } \\
(\mathrm{mm})\end{array}$} & \multirow{2}{*}{$\begin{array}{c}\text { Eggshell } \\
\text { strength, } \\
\text { Čvrstoća ljuske } \\
\left(\mathrm{kg} / \mathrm{cm}^{2}\right)\end{array}$} & \multirow{2}{*}{$\begin{array}{l}\text { Shell weight } \\
\text { Težina } \\
\text { ljuske } \\
\text { (g) }\end{array}$} & \multirow{2}{*}{$\begin{array}{l}\text { Yolk weight } \\
\text { Težina } \\
\text { žumanjka } \\
\text { (g) }\end{array}$} & \multirow[b]{2}{*}{$\begin{array}{c}\text { Albumen weight } \\
\text { Težina bjelanjka } \\
(\mathrm{g})\end{array}$} \\
\hline $\begin{array}{l}\text { Manufacturer } \\
\text { Proizvođač }\end{array}$ & $\begin{array}{c}\text { Storage } \\
\text { Skladištenje }\end{array}$ & & & & & & & \\
\hline \multirow[b]{2}{*}{$A$} & 7 & 55.75 & $76.67^{\mathrm{b}}$ & $0.362^{b}$ & $2.513^{b}$ & $7.57^{\mathrm{b}}$ & 16.19 & $31.98^{\mathrm{b}}$ \\
\hline & 28 & 55.44 & $76.71^{b}$ & $0.423^{a}$ & $2.887^{\mathrm{b}}$ & $7.38^{b}$ & 15.99 & $32.06^{b}$ \\
\hline \multirow[b]{2}{*}{$B$} & 7 & 57.89 & $79.04^{a}$ & $0.380^{\mathrm{b}}$ & $3.518^{\mathrm{a}}$ & $7.89^{a}$ & 15.81 & $34.18^{\mathrm{a}}$ \\
\hline & 28 & 57.45 & $77.97^{\mathrm{ab}}$ & $0.442^{\mathrm{a}}$ & $3.911^{\mathrm{a}}$ & $8.07^{a}$ & 15.84 & $33.52^{\mathrm{a}}$ \\
\hline
\end{tabular}




\begin{tabular}{|c|c|c|c|c|c|c|c|c|}
\hline \multicolumn{2}{|c|}{ Treatments - Tretmani } & \multirow[b]{2}{*}{$\begin{array}{c}\text { Egg weight, } \\
\text { Masa jaja } \\
\text { (g) }\end{array}$} & \multirow{2}{*}{$\begin{array}{c}\text { Shape index } \\
\text { Indeks } \\
\text { oblika } \\
(\%)\end{array}$} & \multirow{2}{*}{$\begin{array}{c}\text { Shell } \\
\text { thickness } \\
\text { Debljina ljuske } \\
(\mathrm{mm})\end{array}$} & \multirow{2}{*}{$\begin{array}{c}\text { Eggshell } \\
\text { strength, } \\
\text { Čvrstoća ljuske } \\
\left(\mathrm{kg} / \mathrm{cm}^{2}\right)\end{array}$} & \multirow{2}{*}{$\begin{array}{l}\text { Shell weight } \\
\text { Težina } \\
\text { ljuske } \\
\text { (g) }\end{array}$} & \multirow{2}{*}{$\begin{array}{l}\text { Yolk weight } \\
\text { Težina } \\
\text { žumanjka } \\
\text { (g) }\end{array}$} & \multirow[b]{2}{*}{$\begin{array}{l}\text { Albumen weight } \\
\text { Težina bjelanjka } \\
\text { (g) }\end{array}$} \\
\hline $\begin{array}{l}\text { Manufacturer } \\
\text { Proizvođač }\end{array}$ & $\begin{array}{c}\text { Storage } \\
\text { Skladištenje }\end{array}$ & & & & & & & \\
\hline \multicolumn{2}{|l|}{ SEM } & 0.473 & 0.500 & 0.009 & 0.141 & 0.099 & 0.313 & 0.501 \\
\hline \multirow{3}{*}{$\begin{array}{l}\text { P-value/ } \\
\text { Vrijednost }\end{array}$} & $\mathrm{P}$ & 0.001 & 0.001 & 0.059 & 0.001 & 0.001 & 0.401 & 0.001 \\
\hline & $S$ & 0.891 & 0.304 & 0.001 & 0.007 & 0.063 & 0.704 & 0.461 \\
\hline & $P \times S$ & 0.430 & 0.271 & 0.927 & 0.948 & 0.991 & 0.780 & 0.569 \\
\hline
\end{tabular}

$\mathrm{P}=$ manufacturer's influence/utjecaj proizvođača; $\mathrm{S}=$ storage influence/utjecaj skladištenja; $\mathrm{P} \times \mathrm{S}=$ interaction of manufacturer and storage/interakcija proizvođača i skladištenja; $\mathrm{a}, \mathrm{b} \mathrm{P}<0.05 ; \mathrm{SEM}=$ mean standard error

Table 2 presents average nutritive value of eggs per $100 \mathrm{~g}$ that is calculated as average weight of eggs of manufacturers $A$ and $B$. Although eggs belonged to the same weight grade, eggs of the manufacturer $B$ weighed $2.45 \mathrm{~g}$ more than the eggs of the manufacturer $A$, which further proves that the eggs of the manufacturer $B$ had energy value greater than $13 \mathrm{KJ}$ and $4 \mathrm{~g}$ of protein more than the eggs of the manufacturer A. Accordingly, in human nutrition, the eggs of the manufacturer B satisfy daily requirements for energy and protein slightly better than the eggs of the manufacturer $A$.

Table 2. Average nutritive value of eggs

Tablica 2. Prosječna nutritivna vrijednost jaja

\begin{tabular}{|c|c|c|c|c|c|}
\hline \multirow[b]{2}{*}{ Indicator/Pokazatelj } & \multirow[b]{2}{*}{$\begin{array}{l}\text { In } 100 \mathrm{~g} \text { of egg weight } \\
\text { U } 100 \mathrm{~g} \text { jajčane mase }\end{array}$} & \multicolumn{2}{|c|}{$\begin{array}{c}\text { Manufacturer A } \\
\text { Proizvođač } A\end{array}$} & \multicolumn{2}{|c|}{$\begin{array}{c}\text { Manufacturer B } \\
\text { Proizvođač } B\end{array}$} \\
\hline & & $\begin{array}{c}\text { Egg } \\
\text { Jaje } \\
55.7 \mathrm{~g}\end{array}$ & $\begin{array}{l}\% \text { of defined intake } \\
\% \text { propisanog unosa }\end{array}$ & $\begin{array}{c}\text { Egg } \\
\text { Jaje } \\
57.9 \mathrm{~g}\end{array}$ & $\begin{array}{l}\% \text { of defined intake } \\
\% \text { propisanog unosa }\end{array}$ \\
\hline Energija/Energy (KJ) & 545 & 302 & 3.6 & 315 & 3.7 \\
\hline $\begin{array}{l}\text { Masti/Fat }(\mathrm{g}) \\
\text {-zasićene masne kiseline/satu- } \\
\text { rated fatty acids (g) }\end{array}$ & $\begin{array}{l}8.7 \\
3.2\end{array}$ & $\begin{array}{l}4.9 \\
1.8 \\
\end{array}$ & $\begin{array}{l}7.0 \\
9.0\end{array}$ & $\begin{array}{c}5.0 \\
1.8 \\
\end{array}$ & $\begin{array}{l}7.0 \\
9.0 \\
\end{array}$ \\
\hline Ugljikohidrati/_Carbohydrates, g & 0.5 & 0.3 & $<1$ & 0.3 & $<1$ \\
\hline $\begin{array}{l}\text { Bjelančevine/ } \\
\text { Protein }(\mathrm{g})\end{array}$ & 12.7 & 7.0 & 14 & 7.4 & 15 \\
\hline Sol/Salt (\%) & 0.5 & 0.3 & 5 & 0.3 & 5.0 \\
\hline
\end{tabular}

Source/Izvor: Own calculation according to the nutritive declaration/Vlastiti izračun prema nutritivnoj deklaraciji

Table 3 overviews indicators of egg freshness that affect egg quality. The height of albumen depended on the duration of storage $(P<0.01)$ and in eggs of both manufacturers it was higher on the $7^{\text {th }}$ day of storage in comparison with the $28^{\text {th }}$ day of storage. If considering this indicator, as well as the Haugh units, eggs of the manufacturer $B$ were of better quality. According to the research of Batkowska et al. (2016), the values of $\mathrm{HU}$ after the $28^{\text {th }}$ day of storage were lower in eggs originating from different keeping systems of laying hens (57.7-60.4 HU) than in our research (64.53 and $66.67 \mathrm{HU})$.

Table 3. Indicators of table eggs freshness

Tablica 3. Pokazatelji svježine konzumnih jaja

\begin{tabular}{|c|c|c|c|c|c|c|}
\hline \multicolumn{2}{|c|}{ Treatments/Tretmani } & \multirow{2}{*}{$\begin{array}{l}\text { Albumen height } \\
\text { Visina bjelanjka } \\
\qquad(\mathrm{mm})\end{array}$} & \multirow[b]{2}{*}{$\mathrm{HU}$} & \multirow{2}{*}{$\begin{array}{l}\text { Yolk color } \\
\text { Boja } \\
\text { žumanjka }\end{array}$} & \multirow[b]{2}{*}{$\begin{array}{c}\text { Yolk pH } \\
\text { pH žumanjka }\end{array}$} & \multirow[b]{2}{*}{$\begin{array}{l}\text { Albumen } \mathrm{pH} \\
\text { pH bjelanjka }\end{array}$} \\
\hline $\begin{array}{l}\text { Manufacturer } \\
\text { Proizvođač }\end{array}$ & $\begin{array}{l}\text { Skladištenje } \\
\text { Storage }\end{array}$ & & & & & \\
\hline \multirow{2}{*}{$A$} & 7 & $5.03^{\mathrm{ab}}$ & $70.36^{\mathrm{ab}}$ & $12.80^{\mathrm{b}}$ & $6.03^{b}$ & $8.75^{\mathrm{c}}$ \\
\hline & 28 & $4.39^{\mathrm{c}}$ & $64.53^{c}$ & $13.10^{\mathrm{a}}$ & $6.21^{\mathrm{a}}$ & $9.03^{\mathrm{a}}$ \\
\hline \multirow{2}{*}{$B$} & 7 & $5.27^{\mathrm{a}}$ & $71.33^{\mathrm{a}}$ & $12.80^{b}$ & $6.06^{b}$ & $8.80^{\mathrm{b}}$ \\
\hline & 28 & $4.68^{b c}$ & $66.67^{\mathrm{bc}}$ & $13.06^{\mathrm{ab}}$ & $6.17^{\mathrm{a}}$ & $8.99^{\mathrm{a}}$ \\
\hline \multicolumn{2}{|l|}{ SEM } & 0.173 & 1.534 & 0.096 & 0.023 & 0.014 \\
\hline \multirow{3}{*}{$\begin{array}{l}\mathrm{P}-\text {-value } \\
\text { Vrijednost }\end{array}$} & $P$ & 0.130 & 0.313 & 0.862 & 0.994 & 0.674 \\
\hline & S & 0.001 & 0.001 & 0.003 & 0.001 & 0.001 \\
\hline & $P \times S$ & 0.901 & 0.705 & 0.863 & 0.193 & 0.006 \\
\hline
\end{tabular}

$\mathrm{P}=$ manufacturer influence/utjecaj proizvođača; $\mathrm{S}=$ storage influence/utjecaj skladištenja; $\mathrm{P} \times \mathrm{S}=$ interaction of manufacturer and storage/interakcija proizvođača i skladištenja; ${ }^{a}, \mathrm{~b}, \mathrm{cP}<0.05 ; \mathrm{SEM}=$ mean standard error 
The yolk colour is an indicator that attracts attention when eggs are used for industrial processing. In our research, as opposed to statements of Jin et al. (2011), eggs stored for 28 days had higher intensity of yolk colour than eggs examined on the $7^{\text {th }}$ day of storage $(P<0.003)$. It was expected that the penetration of water from albumen into the yolk through its membrane would cause the yolk to dilute, to become lighter in colour and heavier. The processes of decomposition of nutrients that occur in yolk and albumen affect the increase of $\mathrm{pH}$ in yolk, which is a consequence of longer storage time $(\mathrm{P}<0.01)$. Increased $\mathrm{pH}$ values in the albumen were influenced by the origin of eggs $(\mathrm{P}<0.001)$ and by storage time $(P<0.006)$. These results are in accordance with those published by Scott and Silversides (2000) and Samli et al. (2005). The eggs produced by manufacturer $\mathrm{B}$ had higher albumen height than eggs produced by manufacturer $A$. During storage, mucin threads of albumen decompose, the content spills, thus reducing the albumen height. The quality of albumen is a standard indicator of egg quality. It depends on breed, egg weight, and environment temperature (Samli et al., 2005). Height and $\mathrm{pH}$ of albumen are indicators of its quality (Scott and Silversides, 2000). During storage, eggs develop oxidative processes, which cause $\mathrm{pH}$ value to increase (Fasiangova and Borilova, 2017). Scheideler et al. (2010) stated that $\mathrm{pH}$ value of fresh egg albumen was 7.6-8.5, and during storage it increased to 9.7 , while $\mathrm{pH}$ of yolk at the same time increased from 6.0 to 6.9. The disulphide bonds got broken, ovomucin was decomposed, which changed the structure of the solid layer of albumen and caused the loss of water (Gajčević et al., 2009; Sheikh et al., 2009). Albumen gets diluted, it spills more and Haugh units get lowered (Lomakina and Mikova, 2006; Kralik et al., 2014). Haugh units (HU) are used as an indicator of egg quality, which are calculated on a basis of albumen thick layer height and egg weight (Haugh, 1937). Papas et al. (2005) pointed out that Haugh units were statistically significantly reduced from 88.5 in fresh eggs to 75.62 in eggs stored for 14 days. Albumen is the highest after laying of eggs, and it decreases during storage period (Silversides and Scott, 2001). Suksombat et al. (2006) tested $60 \mathrm{~g}$ eggs and determined albumen height to be $7-8 \mathrm{~mm}$ and $\mathrm{HU} 89-90$, values of which were greater than in our research, because their research was performed on fresh eggs. Batkowska et al. (2016) determined that during storage of eggs, their air chamber and $\mathrm{pH}$ of albumen got increased, and the $\mathrm{HU}$ decreased. Hanusova et al. (2015) stated that internal quality of eggs started to change right after eggs were laid, therefore it is important that eggs are consumed as soon as possible. They determined that there were differences in quality of eggs laid by different laying hens' breed. Jin et al. (2011) confirmed that shell weight, \% of shell and albumen weight $(\mathrm{P}<0.001)$ decreased during storage. Absolute and relative portion of yolk and $\mathrm{pH}$ of albumen significantly increased $(\mathrm{P}<0.001)$ along with the increase of storage temperature (Jianping, 2014). Jin et al. (2011) pointed out that the decrease in egg weight,
$\mathrm{pH}$ of albumen and $\mathrm{HU}$ was significantly influenced by duration of egg storing. Indicators of albumen quality decrease are $\mathrm{pH}$ values, which are increased during storage period (Samli et al., 2005; Scott and Silversides, 2006). Kralik et al. (2015) stated that the values of albumen $\mathrm{pH}$ and yolk $\mathrm{pH}$ were significantly higher in eggs from younger flock of hens compared to an older flock (pH 8.94 and $\mathrm{pH} 6.07, \mathrm{pH} 8.85$ and $\mathrm{pH}$ 6.01), while the storage conditions influenced the $\mathrm{pH}$ value in such a way that at higher temperature with a longer storage time $\mathrm{pH}$ values were higher. Batkowska et al. (2016) reported pH values of yolk after the $28^{\text {th }}$ day of storage (6.57-6.75) that were higher than our values (6.17-6.21). There was high correlation between egg size and shell thickness (Harms et al., 1990). Iposu et al. (1994) and Silversides (1994) determined significant negative correlation between egg weight and albumen height $(-0.021)$ and between egg weight and Haugh units $(-0.108)$. Similar results were obtained by Sekeroglu et al. (2000) for correlation between egg weight and shape index (0.227), as well as shell strength $(-0.461)$. Scott and Silversides (2000) stated that storing eggs at a room temperature over a longer period of time resulted in the decrease of albumen weight and the increase of $\mathrm{pH}$ values.

\section{CONCLUSION}

The results of the research into the quality of table eggs produced by manufacturer $A$ and $B$ on Croatian market, in conditions of storage that lasted for 7 and 28 days, the following conclusions can be drawn:

- Based on the assessment of energy and protein values, eggs of the manufacturer $B$ had better nutritive value than the eggs of the manufacturer $A$,

The results of the research into quality of eggs on the $7^{\text {th }}$ day of storage indicated that there was statistically significant difference $(P<0.001)$ between manufacturer $A$ and manufacturer $B$ referring to: egg weight, shape index, shell thickness, weight and strength of shell, as well as albumen weight,

After $28^{\text {th }}$ day of storage, there was statistically significant difference $(P<0.001)$ determined for the albumen height, $\mathrm{HU}, \mathrm{pH}$ values of albumen and yolk, and yolk color $(\mathrm{P}=0.003)$,

- Based on the analysis of nutritive values and physical and chemical properties of the eggs during storage, the eggs produced by manufacturer $B$ had better quality than the eggs of the manufacturer $A$.

The eggs of both manufacturers met the requirements defined by the Croatian Regulations on Egg Quality.

\section{ACKNOWLEDGEMENT}

This paper is a part of the research entitled "Research, Production and Medical Testing of Functional Food", performed within the project "The Scientific Centre of Excellence for Personalized Health Care", and financed by the Ministry of Science, Education and Sports of the Republic of Croatia. 


\section{REFERENCES}

1. Burley, R.W., Vadehra, D.V. (1989): The Avian egg. Chemistry and Biology, New York: Wiley Interscience.

2. Batkowska, J., Brodacki, A., Gryzinska, M. (2016): Effects of laying hen system and storage on egg quality. Europ. Poult. Sci. 80.

https://www.researchgate.net/profile/Justyna Batkowska/publication/309566209_Effects_of_laying hen husbandry_system and storage_on_egg_quality/links/5817a3Æ308aeb720f6899b07e.pdf (accessed 1 February 2017)

doi: http://dx.doi.org/10.1399/eps.2016.158

3. Dell ${ }^{\mathrm{TM}}$ Statistica ${ }^{\mathrm{TM}}$, Inc. (2016). STATISTICA (data analysis software system), version 13.2. www.statsoft.com.

4. Farroq, M., Mian, M.A., Ali, M., Durrani, F.R., Asquar, A., Muqarrab, A.K. (2001): Egg traits of Fayomi bird under subtropical conditions. Sarad J. Agric., 17: 141-145.

5. Fasiangova, M., Borilova, D. (2017): Impact of Se supplementation on the oxidation stability of eggs. World's Poultry Science Journal, 73: 175-184. doi: http://dx.doi.org/10.1017/S0043933916000854

6. Gajčević, Z., Kralik, G., Has-Schon E., Pavić, V. (2009): Effects of organic selenium supplemented to layer diet on table egg freshness and selenium content. Italian Journal of Animal Science, 8(2): 189-199.

7. Hanusova, E., Hrnčar, C., Hanus, A., Oravcova, M. (2015): Effect of breed on some parameters of egg quality in laying hens. Acta Fytotechn. Zootechn., 18(1): 20-14. doi: http://dx.doi.org/10.15414/afz.2015.18.01.20-24

8. Harms, R.H., Rossi, A.F., Sloan, D.R., Milles, R.D. Christmas, R.B. (1990): A method for estimating shell weight and correcting specific gravity for egg weight in egg shell quality studies. Poultry Science, 73: 599-602. doi: http://dx.doi.org /10.3382/ps.0690048

9. Hincke, M.T., Nys, Y., Gautron, J., Mann, K., RodriguezNavarro, A.B., Mc Kee, M.D. (2012): The eggshell: structure, composition and mineralization. Frontiers in Bioscience, 17: 1266-1280. doi: http://dx.doi.org/10.2741/3985

10. Iposu, S.O., Onwuka, C.F.I., Eruvbetine, D. (1994): The relationship between selected quality traits and egg size. Niger J. Anim. Prod., 21: 156-160.

11. Jianping, W. (2014): Eggs and egg products processing. In: Food Processing: Principles and Applications, Chapter 19, pp. 437-455, Second Edition (Ed. Clark, S., Jung, S., Lamsal, B.), John Wiley \& Sons, Ltd.

12. Jin, Y.H., Lee, K.T., Lee, W.I., Han, Y.K. (2011): Effects of storage temperature and time on the quality of eggs grom laying hens and peak production. Asian-Aust. J. Anim. Sci., 24(2): 279-284. doi: http://dx.doi.org/10.5713/ajas.2011.10210

13. Kaminska, B.Z., Skraba, B. (1991): Analysis of hen types considering albumen; yolk ratio and its changes during the laying cycle. Proceedings of the 4th European Symposium on the Quality of Poultry products. II Eggs and Egg Products, Doorwerth, Netherlands, pp. 43-49.

14. Kralik, Z., Kralik, G., Grčević, M., Galović, D. (2014): Effect of storage period on the quality of table eggs. Acta Agraria Kaposvariensis, 18(1): 200-206. doi: http://dx.doi.org/10.13140/2.1.3231.3285
15. Kralik, Z., Grčević, M., Radišić, Ž., Škrtić, Z., Kralik, G., Pavičić N. (2015): Effect of different storage conditions and age of hens on quality of table eggs. International Symposium on Animal Science, 9-11 September 2015, Novi Sad. Proceedings and Abstract book (Editor: Prof. Snežana Trivunović, ISBN 978-86-7520-346-9), p. 326331.

16. Lomakina, K., Mikova, K.A. (2006): Study of the factors affecting the foaming properties of egg white - a review. Czech Journal of Food Sciences, 24: 110-111.

17. Panda, P.C. (1996): Shape and texture. In Textbook on Egg and Poultry Technology. First Edition, New Delhi, India.

18. Pappas, A.C., Acamovic, T., Sparks, N.H.C., Surai, P.F., Mc Devitt, R.M. (2005): Effects of supplementing broiler breeder diets with organic selenium and polyunsaturated fatty acids on egg quality during storage. Poultry Science, 84(16): 865-874.

doi: http://dx.doi.org/10.1093/ps/84.6.865

19. Pravilnik o kakvoći jaja (N.N. 115/06.)

20. Samli, H.E., Agna, A., Senkoylu, N. (2005): Effects of storage and physicochemical basis of organization of the yolk and white. In: Egg Quality. A study of the Hen's egg (Ed. Carter, T.C.). Oliver and Boyd, Edinburgh, Scotland, pp. 26-58.

21. Scheideler, S.E., Weber, P., Monsalve, D. (2010): Supplemental vitamin E and Se effects on egg production, egg quality, and egg deposition of $\alpha$-tocopherol and Se. The Journal of Applied Poultry Research, 19: 354360

doi: http://dx.doi.org/10.3382/japr.2010-00198

22. Scott, T.A., Silversides, F.G. (2000): The effect of storage and strain of hen on egg quality. Poultry Science, 79: 1725-1729. doi: http://dx.doi.org/10.1093/ps/79.12.1725

23. Sekeroglu, A., Altuntas, E. (2009): Effects of egg weight on egg quality characteristics. J. Sci. Food Agric., 89: 379-383.

doi: http://dx.doi.org/10.1002/jsfa.3454

24. Sekeroglu, A., Kayaalp, G.T., Satica, M. (2000): The regression and correlation analysis an egg parameters in Denizli poultry. J. Agric. Fac. Cukurova Univ., 15: 69-74.

25. Sheikh, H., Pasha, I., Katiya, A.G. (2009): Factors affecting whipping ability of fresh and stale eggs. Pakistan Journal of Food Sciences, 19: 1-6.

26. Silversides, F.G. (1994): The Haugh unit correction for egg weight is not adequate for comparing eggs from chickens of different lines and ages. J. Appl. Poult. Res., 3: $120-126$

doi: http://dx.doi.org/10.1093/japr/3.2.120

27. Silversides, F.G., Scott, T.A. (2001): Effect of storage and layer age on quality of eggs from two lines of hens. Poult. Sci., 80: 1240-1245.

doi: http://dx.doi.org/10.1093/ps/80.8.1240

28. Suksombat, W., Samitayotin, S., Lounglawan, P. (2006): Effects of conjugated linoleic acid supplementation in layer diet on fatty acid composition of egg yolk and layer performances. Poultry Science, 85: 1603-1609.

doi: http://dx.doi.org/10.1093/ps/85.9.1603 


\section{KVALITETA KONZUMNIH JAJA NA HRVATSKOME TRŽIŠTU}

\section{SAŽETAK}

U radu se istražuju fizikalno-kemijski pokazatelji kakvoće konzumnih jaja na našem tržištu. Istraživanje je provedeno na jajima dvaju različitih proizvođača, "A“ i $B^{\prime \prime}$, i to 7. i 28 . dana skladištenja jaja. Prema Pravilniku o kakvoći jaja (NN 115/06. čl. 9.), jaja se klasiraju na jaja "A“ klase“ ili svježa jaja $i$ jaja "B" klase, namijenjena industrijskoj preradi. S obzirom na težinu, jaja " $A$ " klase razvrstavaju se u četiri razreda: " $X L$ ", "L", " $M$ " $i{ }^{\prime}, S$ ". Naše istraživanje odnosi se na jaja " $M$ " težinskoga razreda, jer se taj razred jaja najviše koristi u našim uvjetima. Od pokazatelja vanjske kvalitete jaja analizirani su indeks oblika (\%), težina jaja (g), težina ljuske (g), čvrstoća $\left(\mathrm{kg} / \mathrm{cm}^{2}\right)$ i debljina (mm) ljuske, a od unutrašnjih pokazatelja težina bjelanjka i žumanjka (g), boja žumanjka, Haugh jedinice (HJ), visina bjelanjka (mm), pH bjelanjka i pH žumanjka. Rezultati naših istraživanja dopuštaju sljedeće zaključke: temeljem procjene energetske i proteinske vrijednosti, jaja proizvođača „B“ odlikuju se boljom nutritivnom vrijednošću od jaja proizvođača „A“. Rezultati istraživanja kvalitete jaja 7. dana skladištenja pokazali su da postoji statistički značajna razlika $(P<0,001)$ između proizvođača jaja " $A^{\prime \prime}$ i „B" u težini jaja, indeksu oblika, debljini ljuske, težini i čvrstoći ljuske, kao i težini bjelanjka. Nakon 28. dana skladištenja, utvrđena je statistički značajna razlika $(P<0,001)$ u visini bjelanjka, $H J$, pH vrijednostima bjelanjka i žumanjka te boji žumanjka $(P=0,003)$. Temeljem analize nutritivne vrijednosti $i$ fizikalno-kemijskih svojstava jaja tijekom skladištenja, jaja proizvođača „B“ odlikuju se boljom kvalitetom od jaja proizvođača „A“. Jaja obaju proizvođača zadovoljavaju uvjete propisane hrvatskim pravilnikom o kakvoći jaja.

Ključne riječi: konzumno jaje, kvaliteta, skladištenje, „M“" težinski razred

(Received on 7 March 2017; accepted on 19 April 2017 - Primljeno 7. ožujka 2017.; prihvaćeno 19. travnja 2017.) 